\title{
Substancje bioaktywne form wyjściowych pszenicy do hodowli nowych odmian w aspekcie produkcji żywności funkcjonalnej - wpływ warunków suszy w sezonie wegetacyjnym 2015 roku
}

\author{
Bioactive substances of wheat input forms for new breeding cultivation in the aspect \\ of functional food production
}

\author{
Wioletta M. Dynkowska ${ }^{\bowtie}$, Małgorzata R. Cyran
}

\author{
Zakład Biochemii i Fizjologii Roślin, Instytut Hodowli i Aklimatyzacji Roślin—- Państwowy Instytut Badawczy, \\ Radzików \\ e-mail: w.dynkowska@ihar.edu.pl
}

\begin{abstract}
Substancje bioaktywne, posiadające zdolność modyfikowania funkcji fizjologicznych i metabolicznych organizmu, stanowią obszar coraz większego zainteresowania w kontekście ochrony zdrowia. Oceniono 45 linii pszenicy ozimej ze zbioru 2015 roku, których wegetacja przebiegała w warunkach suszy w sześciu różnych lokalizacjach stacji hodowli roślin. Stwierdzono występowanie korelacji pomiędzy zawartością arabinoksylanów rozpuszczalnych oraz ich indeksem masy cząsteczkowej a lepkością wodnego ekstraktu. Stres suszy powodował wzrost długości łańcuchów arabinoksylanów rozpuszczalnych.
\end{abstract}

Słowa kluczowe: pszenica ozima, substancje bioaktywne, związki fenolowe, susza

Bioactive substances, which have the ability to modify the physiological and metabolic functions of the body, constitute an area of growing interest in the context of health protection. 45 lines of winter wheat from the 2015 harvest were assessed, the vegetation of which took place in drought conditions in six different locations of plant breeding stations. There was a correlation between the content of soluble arabinoxylans and their molecular weight index and the viscosity of the aqueous extract. The drought stress caused an increase in the length of the soluble arabinoxylan chains.

Key words: winter wheat, bioactive substances, phenolic compounds, drought

Substancje bioaktywne, posiadające zdolność modyfikowania funkcji fizjologicznych i metabolicznych organizmu, stanowią obszar coraz większego zainteresowania w kontekście ochrony zdrowia. Zawartość polisacharydów rozpuszczalnego błonnika pokarmowego przyczynia się do podniesienia lepkości treści pokarmowej jelita cienkiego tym samym ograniczając strawność pokarmów wysokoskrobiowych i spowalniając wchłanianie glukozy. Charakterystyka materiałów hodowlanych pszenicy w zakresie potencjału lepkiego ziarna, zawartości i składu polisacharydów błonnika pokarmowego oraz określenia zawartości związków fenolowych, jako podstawy do wskazania linii pszenic odpowiednich do hodowli nowych odmian o podwyższonej koncentracji związków bioaktywnych stanowiło cel niniejszych badań.

Oceniono 45 linii pszenicy ozimej ze zbioru 2015 roku, których wegetacja przebiegała w warunkach suszy w sześciu różnych lokalizacjach stacji hodowli roślin. Analizę lepkości wodnego ekstraktu ziarna $(1: 3 ; \mathrm{w} / \mathrm{v})$ przeprowadzono na reometrze Brookfield LVDV-III Ultra $\mathrm{CP}$ w temperaturze $30^{\circ} \mathrm{C}$ (Cyran, Ceglińska, 2011).
Całkowitą ilość związków fenolowych w ekstrakcie metanolowym analizowano kolorymetrycznie, wykorzystując odczynnik Folina i Ciocalteu'a (Horszwald i in., 2010). Oznaczenie polisacharydów nieskrobiowych wykonano za pomocą chromatografii gazowej po wcześniejszym wytrawieniu enzymatycznym skrobi i białka, hydrolizie oczyszczonych frakcji polisacharydowych i upochodnieniu uwolnionych cukrów prostych do lotnych pochodnych (Englyst, Cummings, 1984).

Średnia wartość poziomu lepkości ekstraktu ziarna badanych linii pszenicy $(2,93 \mathrm{mPa} \cdot \mathrm{s})$ była aż o 70\% wyższa w stosunki do średniej lepkości ekstraktu ziarna $(1,73 \mathrm{mPa} \cdot \mathrm{s})$ uzyskanej dla linii pszenicy pochodzących ze zbioru w 2013 roku w tych samych lokalizacjach, uprawianych w typowych warunkach klimatycznych. Zakres zmienności tego parametru wahał się od 1,71 do $5,26 \mathrm{mPa} \cdot \mathrm{s}$ i był prawie dwukrotnie szerszy niż ten obserwowany w materiałach z 2013 roku $(1,40-2,30 \mathrm{mPa} \cdot \mathrm{s})$.

Średnia zawartość arabinoksylanów rozpuszczalnych $(1,04 \%$ s.m. $)$ w ziarnie pszenicy ze zbioru w 2015 roku i ich zakres zmienności 
$(0,75-1,39 \%$ s.m. $)$ nie różniły się istotnie od wartości tych parametrów uzyskanych dla populacji z roku 2013 (0,96\% s.m. i 0,66-1,28\% s.m.). Natomiast indeks masy cząsteczkowej arabinoksylanów rozpuszczalnych $\mathrm{w}$ formach pszenicy z 2015 roku, wyrażony lepkością ekstraktu ziarna przypadającej na jednostkę masy arabinoksylanów (wartość średnia, 2,82) był o $55 \%$ wyższy w stosunku do jego wartości obserwowanej w liniach z 2013 roku $(1,82)$; przesunął się również zakres zmienności tego parametru (2,22-3,79, dla populacji z 2015; 1,38-2,34, dla form z 2013 roku).

Stwierdzono występowanie korelacji pomiędzy zawartością arabinoksylanów rozpuszczalnych oraz ich indeksem masy cząsteczkowej a lepkością wodnego ekstraktu, jednakże drugiej zależności nie odnotowano w formach wyhodowanych w 2015 roku. Ekstrahowalność arabinoksylanów, zawartość nierozpuszczalnych polisacharydów błonnika pokarmowego oraz zawartość związków fenolowych ogółem nie różniły się znacząco od ich wartości otrzymanych dla populacji uprawianych $\mathrm{w}$ typowych warunkach klimatycznych.
Stres suszy powodował wzrost długości łańcuchów arabinoksylanów rozpuszczalnych, tym samym wzrastał potencjał lepki ziarna pszenicy, czego konsekwencją było polepszenie jego wartości prozdrowotnej.

\section{Literatura}

Englyst H., Cummings J. H. Simplified method for the measurement of total non-starch polysaccharides by gas-liquid chromatography of constituent sugars as alditol acetates. Analyst, 1984, 109: 937 - 942.

Cyran M. R., Ceglińska A. Genetic variation in the extract viscosity of rye (Secale cereale L.) bread made from endosperm and wholemeal flour: impact of highmolecular-weight arabinoxylan, starch and protein. Journal of the Science of Food and Agriculture, 2011, 91: $469-479$.

Horszwald A., Morales F. J., del Castillo M. D., Zieliński H. Evaluation of antioxidant capacity and formation of processing contaminants during rye bread making. Journal of Food and Nutrition Research, 2010, 49 (3): $149-159$.

\section{Podziekowanie}

Autorki sktadaja serdeczne podziękowania hodowcom ze stacji Hodowli Roślin w Modzurowie, Smolicach, Antoninach, Choryni, Strzelcach $i$ Polanowicach za udostepnienie ziarna materiatów hodowlanych pszenicy do analiz fizyko-chemicznych.

$\underline{\text { Sponsorzy konferencji Dzień Młodego Naukowca } 2018}$

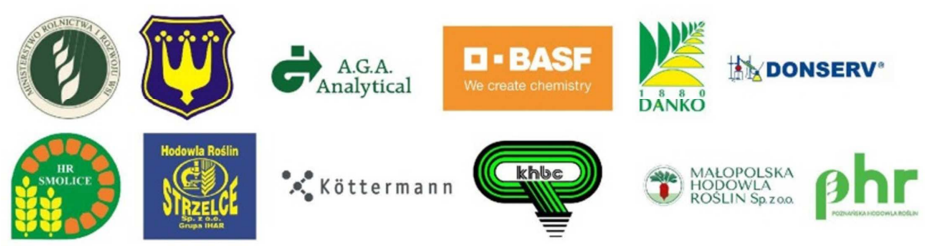

